\title{
THE ROLE OF PERSONAL MOTIVATION IN SUSTAINABLE PURCHASING PRAGTIGES
}

\author{
Gyöngyi Vörösmarty ${ }^{\mathbf{1}}$ and Imre Dobos ${ }^{2 *}$ \\ ${ }^{1)}$ Corvinus University Budapest, Hungary \\ ${ }^{2)}$ Budapest University of Technology and Economics, Hungary
}

Please cite this article as:

Vörösmarty, G. and Dobos, I., 2019. The Role of Personal Motivation in Sustainable Purchasing Practices. Amfiteatru Economic, 21(50), pp. 121-137.

\section{Article History}

Received: 27 September 2018

Revised: 17 November 2018

Accepted: 20 December 2018

DOI: $10.24818 / \mathrm{EA} / 2019 / 50 / 121$

\begin{abstract}
There is growing interest in identifying the drivers of and barriers to green purchasing, and many publications focus on motivational factors. However, the effects of these factors on the activities and means applied to sustainable purchasing are seldom investigated. This paper addresses this research gap and examines the impact of the motivational factors on green purchasing practices of the companies'. This paper also emphasises the role and motivational background of personal attitudes and reveals that there are differences among them. Based on the literature, a questionnaire was developed and a survey was completed in Hungary. The answers indicate that positive and compliant personal attitudes of purchasing managers' have different drivers and barriers, while differences are also present in sustainable purchasing practices. Purchasing managers with a positive personal attitude have better green purchasing practices but mainly concerning product performance level activities, which do not require in-depth green management information.
\end{abstract}

Keywords: sustainable purchasing, motivation, purchasing practices, sustainable supply chain management

JEL Classification: C10, M11, Q01

\footnotetext{
* Corresponding author, Imre Dobos - dobos@kgt.bme.hu
} 


\section{Introduction}

There is growing interest in the academic literature regarding green and sustainable purchasing and supply management of firms'. Sustainability issues are addressed from various aspects in scientific literature, such as bioeconomy, blue economy, circular economy etc. Bioeconomic practices are broadly investigated in management literature (Torjai et al., 2015). Green purchasing is important in the context of the transition to a bioeconomy as the green purchasing means a broader framework. Consumer buying is often examined in green context (e.g. Kaufman et al., 2012) and the behaviour of firms is often analysed as well. (Zhu et al. 2007) This paper joins this discussion by investigating the relationship between the origin of motivation and firms' green purchasing practices. Several drivers of and barriers to these practices have been identified in the literature (Appolloni et al., 2014). However, only limited results are available that address how the identified motivational items affect the actual green purchasing practices of companies. This paper addresses this research gap.

The literature investigates the advantages of emphasising environmental issues in purchasing (e.g., Rao and Holt, 2005; Zhu et al., 2008). Although green purchasing is evidently considered beneficial, the investigations of firms' green purchasing practices present a mixed picture of implementation (e.g., Tate et al., 2012). A potential explanation for these differences is the human factor disparities, which have not yet been investigated in this context.

In a previous study (Vörösmarty et al., 2011), a motivational model was developed in which three motivational attitude types were described and tested through interviews. The three motivational attitude types are the avoidance of negative effects, compliance with expectations, and positive results. This paper focuses on how these three motivational attitudes relate to green purchasing practices.

To meet this goal, section 2 presents the results of the literature review regarding the different approaches and the measurement of green purchasing practices and their motivations. In section 3, the results of a survey are presented, where 109 questionnaires were completed by managers of Hungarian organisations from early 2015 (response rate approx. 16\%). To analyse the survey data, the paper uses methodology of multivariate data analysis. The statistical methods were used according to the general standards described in literature e.g. Chatfield et al., 2018 .

Accordingly, this paper analyses the effects of the perceived drivers, barriers and motivational attitudes on the practices of green purchasing management.

\section{Literature review}

The green purchasing literature is rapidly growing. Two decades ago, the first publications focused on the identification of green practices. In an early classification of green purchasing strategies, Min and Galle (1997) emphasised the role of green purchasing in source reduction (recycling, reuse, source changes and control) and waste elimination. Carter et al. (1998) used a similar definition of environmental purchasing that consists of purchasing's involvement in activities that include the reduction, reuse and recycling of materials. These studies examined production-related spending and the tactical level of the material supply process. With this focus, it was logical to consider the relevancy of green purchasing mainly to manufacturers. 
However, green purchasing is also relevant to non-manufacturing companies. Green purchasing practices were identified as a key area of strategic purchasing management in the study by Arnold et al. (1999). These authors implemented a survey of the manufacturing and service industries in 7 countries in which they measured green purchasing practices with 13 activities. These activities are beyond the previous research's supply-oriented approach because they include the involvement of purchasing in more strategic activities, such as supplier management activities. A broadened concept of green purchasing was advanced in the following definition by Zsidisin and Siferd (2001, p 69): 'Environmental purchasing for a firm is a subset of purchasing policies held, actions taken and relationships formed in response to concerns associated with the natural environment'. The policies and roles of green supply management have a diverse focus. Bowen et al. (2006) identify the 3 green purchasing categories of product-based green supply, greening the supply process and advanced green supply.

Many recent studies position green purchasing practices in the broader context of green supply chain management (GSCM). This approach emphasises the internal and external embeddedness of green purchasing (Zhu et al., 2005, Min and Kim, 2012) or the supply management role of purchasing (Tachizawa et al., 2015; Vijayvargy et al., 2017, Zhu et al., 2013). These studies mainly use similar measures to describe green practices; however, the supply chain approach ensures the integration of design, logistics, and supply management activities in an environmentally conscious manner.

\subsection{Green purchasing activities}

The literature is rich in publications that study green purchasing practices. However, only a few studies provide measures of green purchasing activities, and definitions indicate that some researchers have already considered it in the GSCM context. In relying on the previously cited definition by Zsidisin and Siferd (2001), Table no. 1 provides a review of the green purchasing practices examined in the literature that indicate that a common set of activities have been identified.

Table no. 1: Green purchasing practices

\begin{tabular}{|c|c|c|}
\hline & Short description & Reference \\
\hline \multicolumn{3}{|l|}{ Internal integration } \\
\hline $\begin{array}{l}\text { A) Integration into } \\
\text { specification } \\
\text { development }\end{array}$ & $\begin{array}{l}\text { Green aspects are considered during the } \\
\text { preparation of specifications together with } \\
\text { purchasing (source reduction, reusability, and } \\
\text { reducing dangerous materials and packaging) }\end{array}$ & $\begin{array}{l}\text { Arnold et al. (1999), } \\
\text { Hasan (2013) }\end{array}$ \\
\hline $\begin{array}{l}\text { B) Integration into } \\
\text { design and process } \\
\text { development }\end{array}$ & $\begin{array}{l}\text { Purchasing is involved in product design and } \\
\text { process development and considers } \\
\text { environmental aspects, reusability, recycling } \\
\text { less hazardous content, less hazardous } \\
\text { processes, and waste minimisation }\end{array}$ & $\begin{array}{l}\text { Carter et al. (1998), } \\
\text { Arnold et al. (1999), } \\
\text { Zhu et al. (2005), Hasan } \\
\text { (2013), Zhu et al. } \\
\text { (2013), Vijayvargy et } \\
\text { al. (2017) }\end{array}$ \\
\hline $\begin{array}{l}\text { C) Integration into } \\
\text { reverse logistics } \\
\text { processes/investment } \\
\text { recovery }\end{array}$ & $\begin{array}{l}\text { The collection and reuse of used } \\
\text { materials/products, reuse of defective products, } \\
\text { sale of excess inventory and materials, and sale } \\
\text { of scrap and used material }\end{array}$ & $\begin{array}{l}\text { Arnold et al. (1999), } \\
\text { Zhu et al. (2005), Zhu et } \\
\text { al. (2013), Vijayvargy } \\
\text { et al. (2017) }\end{array}$ \\
\hline $\begin{array}{l}\text { D) Integration into } \\
\text { environmental } \\
\text { systems }\end{array}$ & Company-wide environmental audits & $\begin{array}{l}\text { Zhu et al. (2005), Hasan } \\
\text { (2013), Zhu et al. } \\
(2013) \text {, Vijayvargy et } \\
\text { al. (2017) }\end{array}$ \\
\hline
\end{tabular}




\begin{tabular}{|c|c|c|}
\hline & Short description & Reference \\
\hline \multicolumn{3}{|l|}{$\begin{array}{l}\text { Supplier-related } \\
\text { activities }\end{array}$} \\
\hline $\begin{array}{l}\text { A) Supplier evaluation } \\
\text { and product } \\
\text { restrictions }\end{array}$ & $\begin{array}{l}\text { Supplier selection includes measures that } \\
\text { consider the environmental performance of the } \\
\text { product (e.g., an evaluation of the environmental } \\
\text { requirements for purchased items and their } \\
\text { packaging, product lifecycle analysis, product } \\
\text { content restrictions, and disclosure of the } \\
\text { environmental attributes of the product content } \\
\text { by the supplier is required) }\end{array}$ & $\begin{array}{l}\text { Carter et al. (1998) } \\
\text { Zhu et al. (2005), Zhu et } \\
\text { al. (2013) }\end{array}$ \\
\hline B) Supplier assessment & $\begin{array}{l}\text { Supplier evaluation includes environmental } \\
\text { requirements for the suppliers' operations (e.g., } \\
\text { supplier is required to be ISO } 14000 \text { compliant, } \\
\text { and an environmental assessment of the } \\
\text { suppliers' processes, supplier auditing) }\end{array}$ & $\begin{array}{l}\text { Arnold et al. (1999), } \\
\text { Zhu et al. (2005), Zhu et } \\
\text { al. (2013), Tachizawa et } \\
\text { al. (2015), Vijayvargy } \\
\text { et al. (2017) }\end{array}$ \\
\hline $\begin{array}{l}\text { C) Supplier management } \\
\text { and cooperation with } \\
\text { suppliers }\end{array}$ & $\begin{array}{l}\text { Promoting the suppliers environmental } \\
\text { performance and cooperating with the supplier } \\
\text { (e.g., ask suppliers to commit to waste reduction } \\
\text { goals, setting environmental standards for } \\
\text { suppliers, cooperation with suppliers to develop } \\
\text { environmentally better products, and educate } \\
\text { suppliers on environmental issues) }\end{array}$ & $\begin{array}{l}\text { Arnold et al. (1999), } \\
\text { Zhu et al. (2005), Zhu et } \\
\text { al. (2013), Tachizawa et } \\
\text { al. (2015) }\end{array}$ \\
\hline
\end{tabular}

As the results of the literature review show, a common set of activities have been identified. These activities determine the integration level of purchasing in internal processes and supplier management.

\subsection{Drivers of and barriers to green purchasing}

Although there is consensus in the literature regarding the importance of green purchasing and supply management, there is an evident gap between the desirability of green purchasing and the slow (or diverse) improvements in company practices. Relationship between supply chain practices and firm performance is identified (Olah et al., 2018). However, the relationship between green purchasing practices and performance outcomes has been the subject of numerous studies, but the results are mixed. Carter et al. (2000), Zhu and Sarkis (2004) and Green et al. (2012) found that there was a positive relationship between green initiatives and the economic performance of organisations. González-Benito et al. (2016) revealed that green purchasing management improves the performance of the purchasing function, although the impact is greater when the organization forges lasting alliances with its suppliers. However, other authors (e.g. Vachon and Klassen, 2006, Zhu et al., 2007) found no significant relationships between green supply chain initiatives and economic performance outcomes.

These inconsistent results raise several questions. What are the influences that affect the adoption of green practices? What are the motivational factors that support or discourage green purchasing?

The comprehensive literature review of Walker et al. (2008) identified 28 drivers and 13 barriers. The results of the completed interviews revealed that external drivers and barriers are stronger than internal ones. Mathiyazhagan et al. (2013) investigated the barriers of GSCM. Their literature review identified 26 barriers, and Interpretive Structural Modelling 
(ISM) was used to study by survey the mutual influences among the twenty-six barriers. This examination revealed that the supplier barriers were the dominant barriers in the Indian auto component manufacturing industries in GSCM implementation, especially in maintaining environmental awareness. In addition to these two comprehensive studies, many other publications have important results (e.g., Huang et al. 2015; Younis et al. 2016).

The drivers and barriers have been tested in several industries and countries. Carter et al. (1998) compared US firms with German firms and identified the importance of the factors that are close to the individual (e.g., top and middle management support and training). Based on US company interviews (14 years later), Giunipero et al. (2012) found that top management initiatives and government regulations drove purchasing and supply management sustainability efforts, while investments in sustainability and economic uncertainty hindered these programmes. Mathiyazhagan et al. (2015) emphasised the role of external pressures, social responsibility and pressure for new economic opportunities and energy savings in the Indian mining and mineral industry. Differences in size were also investigated (Huang et al., 2015, Theyel and Hoffman, 2015).

Because of the heterogeneous background of the published papers, the results are not consistent, and it is difficult to identify trends over the last twenty years. Additionally, the issue of influential factors is complex. Therefore, these publications have attempted to identify the relationships among the motivating factors and describe their influences. The early article by Min and Galle (1997) identified the practices that focus on avoiding environmental statutes as reactive and the practices that embed environmental goals in the long-term corporate policy as proactive. However, it has been only recently that the research has begun to address sustainable or green business models. Zhu et al. (2013) identified normative, coercive and mimetic pressures based on institutional theory. Hsu et al. (2013) developed four groups of drivers, namely, regulatory measures, customer pressure, sociocultural responsibility and competitor pressure. Their results showed that the firms that perceived more pressure to adopt green supply chain initiatives were further along in their development of green supply chain organisation capabilities. Kuei et al. (2015) studied the practices of Chinese companies and concluded that the main drivers and barriers depended on the position of the firm in the supply chain, as because focal firms and upstream and downstream firms indicated different critical performance factors to improve green supply chain practices.

The recent literature has discussed the connection between motivation and green purchasing practices. Appolloni et al. (2014) developed a conceptual model to connect environmental antecedents to how companies actually implement green purchasing. Lintukangas et al. (2016) found that quality and brand risk management ability are positively related to the adoption of green supply management, whereas price and cost risk management ability have the reverse effect. (Popp et al., 2018) Relying on previous results, the following sections of this paper will emphasise the role of the human factor.

\subsection{The relationship between personal attitudes and green purchasing practices}

Human attitudes have just recently been recognised as an important contributor to greener supply chain management (Jabbour and de Sousa Jabbour, 2016). Motivation studies have often emphasised the role of management, but the literature has failed to provide results regarding the attitudes of the people who are responsible for purchasing. 
In an earlier study (Vörösmarty et al., 2011), 3 groups of motivational attitudes towards sustainable purchasing were identified as a conceptual model. In this model the main difference between the groups was the personal motivation of individuals and the research led to the following attitude groups: the avoidance of negative effects; compliance with expectations; and achievement of positive goals. The assumption was that the attitude groups explained the relationship between motivation and green purchasing activity.

The avoidance of negative effects characterises a group of purchasers whose main goal is to avoid negative consequences, e.g., the payment of a penalty or a sales decrease due to negative publicity. With these motivations, companies (through purchasing or sourcing managers) act only if they feel endangered.

Compliance with expectations means that there is an initiative for the purchasing function (or for the organisation) that must be satisfied. Here, the action is provided to the company, and it may be an initiative of the owners/top management (such as introducing ISO 14001 or an environmental compliance programme). The action may also originate from competition (e.g., other competitors already have ISO 14001 certification). Therefore, with this motivation, the action is specified, and if it is completed, the requirements are fulfilled.

Positive achievements mean that actions (or the formation of activities) are performed as sustainable activities, and companies and their stakeholders realise positive benefits. Additionally, these positive benefits are often linked to the financial performance of firms. (e.g., good PR through increasing sales). However, a positive benefit may be personal, for example, when a person is satisfied because of his or her or the company's environmentally conscious actions.

Purchasing and supply functions are motivated in all three ways, but the manner in which they motivate managers may be different.

This conceptual model was developed based on interview results. This model provided a testable framework to validate the relationships between the personal attitude of the purchaser and the level of involvement in green purchasing.

\section{Research methods}

To investigate the relationship between motivation and green purchasing practices, a questionnaire was developed. To construct the survey questions about green purchasing activities and the drivers of and barriers to green purchasing, earlier surveys (referenced in the literature review) were used. The structure of purchasing activities followed the structure of Table no. 1 by splitting activities into two groups (internal collaboration and supplierrelated activities). Three trial queries were developed with highly experienced procurement professionals, who are the members of the CPO (Chief Purchasing Officers) Club to test the intelligibility of the questions. The questionnaire was distributed electronically and in a paper format. The answers were anonymous. The questionnaire was distributed to a list of managers from 500 companies based in Hungary. The list was used by the universities research centre for a questionnaire survey in a previous project. Because the initial response rate was low, in a second round, the companies were contacted by telephone. Because the number of responses was still low (82, a response rate of $16 \%$ ), the members of a professional association were contacted. A total of 109 responses were collected. The respondents are purchasing and supply leaders, purchasing managers, and in the case of smaller companies, other managers who were responsible for purchasing (e.g., logistics managers). 
The companies were mostly large or medium-sized companies that have more than 20 employees and an income greater than 1.5 million Euros. The companies represented several industries including the manufacturing and service industries, and two answers came from the purchasing managers of governmental institutions. The sample is not representative, but it provides a good basis for analysis. The reasons for not responding included a lack of time, concerns regarding data privacy, and a lack of interest. Because of the lack of interest, it can be assumed that the results regarding the current practices provide a more favourable picture than reality.

The aim of the following analyses was to validate the above described three personal attitude types. The following hypothesises were developed and tested:

H1. The motivational attitude groups differ in terms of the motivational factors.

H2. The motivational attitude groups differ in terms of green their green purchasing activities.

\section{H2.A There are differences in internal collaboration.}

H2.B There are differences in supplier-related activities.

Personal motivation was measured by self-evaluation. The respondents were asked to indicate which option best described their attitude. Because the responses were anonymous, the respondents should not have felt pressure to indicate a better attitude than the attitude that they actually had.

Table no. 2 indicates the distribution of the answers among the attitude groups. The number of respondents in the attitude group of 'avoidance of negative affects' is low. Because the non-response rate was high, the reasoning for not responding suggests that the ratio of this group may be higher. Because of the low response number, the interpretation of the results is not statistically valid.

Table no. 2: The distribution of answers

\begin{tabular}{|l|c|}
\hline Attitude type & No. of responses \\
\hline Avoidance of negative effects (Avoidance) & 15 \\
\hline Compliance with expectations (Compliance) & 63 \\
\hline Achievement of positive goals (Positive) & 31 \\
\hline
\end{tabular}

The questionnaire consisted of 4 parts: general data about the respondents' firm, general environmental policy, green purchasing activities, drivers and barriers to green purchasing. The questions related to the application of the activities, and the motivational factors were measured on a 1-5 scale. The differences in the motivational groups were validated by an ANOVA analysis.

\section{Survey results}

First, the organisational background of the attitude groups is described. Next, the motivation and green purchasing practices are analysed.

\subsection{Organisational background of the motivational groups}

Before investigating the attitude groups and their practices, we describe the organisational background. Some literature identifies differences according to firm size (e.g., Huang et al., 
2015; Theyel and Hofmann, 2015). Thus, the distribution of the motivational groups according to firm size is presented first. (SMEs were defined as having fewer than 250 employees and sales revenue of less than approximately 33 million Euro.) The sample contained 61 SMEs and 46 large companies. (Two answers could not be categorised due to missing data.)

As Table no. 3 presents, the ratios of positive answers were the same in the two groups. However, the ratio of the compliance group was higher among respondents working for large firms, while the ratio of the avoidance group was higher among respondents working for SMEs. These results obviously relate to the fact that large companies have a greater share of environmental management systems. (In the sample, $30.73 \%$ of SMEs and $70.83 \%$ had ISO 14001 certification.)

Table no. 3: The distribution of answers according to firm size

\begin{tabular}{|l|l|l|}
\hline Attitude type & SME & Large firms \\
\hline Avoidance of negative effects (Avoidance) & $17.74 \%$ & $8.89 \%$ \\
\hline Compliance with expectations (Compliance) & $53.23 \%$ & $62.22 \%$ \\
\hline Achievement of positive goals (Positive) & $29.03 \%$ & $28.89 \%$ \\
\hline
\end{tabular}

As Table no. 4 presents, personal attitudes fail to show a strong relationship with the type of operations. The ratio of positive respondents was slightly higher among those who were working at manufacturing firms, while the ratio of avoidance respondents was somewhat higher at service firms. (Here, the share of those having ISO 14001 certification was nearly the same in the two groups.)

Table no. 4: The distribution of answers according to the type of operations

\begin{tabular}{|l|l|l|}
\hline Attitude type & Production & Service \\
\hline Avoidance of negative effects (Avoidance) & $8.51 \%$ & $14.63 \%$ \\
\hline Compliance with expectations (Compliance) & $61.70 \%$ & $60.98 \%$ \\
\hline Achievement of positive goals (Positive) & $29.79 \%$ & $24.39 \%$ \\
\hline
\end{tabular}

The results in Table no. 5 indicate that the attitude of the respondents was related to the existence of their firm's environmental system. The ratio of those having such systems was the highest among those in the compliance attitude group and was the lowest for those in the avoidance attitude group.

These results revealed that personal attitude is influenced by company background but not determined by it. The following analysis focuses on the motivational factors.

Table no. 5: The existence of environmental systems in the attitude groups

\begin{tabular}{|l|l|l|l|}
\hline Attitude type & $\begin{array}{c}\text { Environmental } \\
\text { management } \\
\text { system }\end{array}$ & $\begin{array}{c}\text { ISO } \\
14001 \\
\text { certificate }\end{array}$ & $\begin{array}{c}\text { Environmental } \\
\text { compliance and } \\
\text { auditing programme }\end{array}$ \\
\hline $\begin{array}{l}\text { Avoidance of negative effects } \\
\text { (Avoidance) }\end{array}$ & $26.67 \%$ & $25.42 \%$ & $25.86 \%$ \\
\hline $\begin{array}{l}\text { Compliance with expectations } \\
\text { (Compliance) }\end{array}$ & $66.67 \%$ & $57.14 \%$ & $59.68 \%$ \\
\hline $\begin{array}{l}\text { Achievement of positive goals } \\
\text { (Positive) }\end{array}$ & $58.06 \%$ & $48.39 \%$ & $48.39 \%$ \\
\hline
\end{tabular}




\subsection{Personal attitudes and motivational factors}

To analyse the motivational differences in the individual attitudes, 17 motivational factors were considered after a review of the literature results and discussions with industrial experts. (The list of the 17 motivational factors are listed in appendix 1.) Here, the influence of these factors, which were earlier described as drivers or barriers, was tested. In later sections, they will be referred to as motivational factors.

The results indicate that for the entire sample, the most influential factor is environmental regulations and law (4.20), the second most influential is the cost saving target (3.98), the third most influential is the customer/market demand (3.95), the fourth most influential factor is top management support (3.91), and the fifth most influential item is the value of the purchase (3.88). Therefore, according to the sample, green purchasing practices are mostly influenced by stakeholders (top management, regulatory bodies, and customers). Other stakeholders, such as competitors and local communities, are among the least important influences. The motivational factors that reflect the professional environment (such as supply chain requirements, the number of suppliers, and production/operation attributes) are not among the most influential factors.

The results show that the answers from the avoidance of negative effects group differ in most cases. However, the number of responses was low, which indicates that this group should be further analysed in subsequent research.

Table no. 6 reveals that there are differences among the groups. Environmental regulations are the most important motivation for the compliance and the positive groups. However, there are differences in the order of importance for the subsequent motivational factors. For the compliance group, the motivational factors, that reflect the expectations of stakeholders are the most prominent. For the positive group, company attributes are the most important.

Table no. 6: The most important motivational factors

\begin{tabular}{|l|c|l|l|l|c|}
\hline \multicolumn{1}{|c|}{ Avoidance } & & \multicolumn{1}{|c|}{ Compliance } & & \multicolumn{1}{c|}{ Positive } & 4.16 \\
\hline Value & 3.80 & $\begin{array}{l}\text { Environmental } \\
\text { regulations, laws }\end{array}$ & 4.37 & $\begin{array}{l}\text { Environmental } \\
\text { regulations, laws }\end{array}$ & 4.16 \\
\hline $\begin{array}{l}\text { Cost saving } \\
\text { targets }\end{array}$ & 3.67 & $\begin{array}{l}\text { Customer/market } \\
\text { demand }\end{array}$ & 4.11 & $\begin{array}{l}\text { Production/operation } \\
\text { attributes }\end{array}$ & 3.97 \\
\hline $\begin{array}{l}\text { Environmental } \\
\text { regulations, laws }\end{array}$ & 3.60 & Cost saving targets & 4.10 & Defined specification & 3.90 \\
\hline $\begin{array}{l}\text { Customer/market } \\
\text { demand }\end{array}$ & 3.40 & $\begin{array}{l}\text { Top management } \\
\text { support }\end{array}$ & 4.03 & $\begin{array}{l}\text { Customer/market } \\
\text { demand }\end{array}$ & 3.90 \\
\hline $\begin{array}{l}\text { Top management } \\
\text { support }\end{array}$ & 3.40 & $\begin{array}{l}\text { Expectation of the } \\
\text { owners/parent comp. }\end{array}$ & 3.94 & Cost saving targets & \\
\hline
\end{tabular}

The results of the ANOVA analyses indicate that there are differences in only 3 cases. The compliance group attributed higher importance to 'the expectation of the owner or parent-company' (the influence of the item is 0.55 higher, and the significance level is 0.028 ). The positive-attitude group indicated a higher influence of 'the availability of environmental information' (this influence is 0.47 higher, and the significance level is 0.045). These differences are connected to the core of the research model of personal attitudes. The major stakeholder of the compliance group is the owner/parent company, which is the major driving force. The assumption was that top management support would be higher (it was higher but 
not significantly). Similarly, regulatory measures were supposed to be higher for the compliance group (it was higher but not significantly). A discussion of the results with industry experts identified the explanation that regulations are major drivers, but considerably more actions are taken at many companies than the actions that are prescribed by the law or regulations. The positive group seeks new solutions, and what frequently discourages them is a lack of information regarding useable products or practices.

The third difference related to the expectations of the local communities. The influence was higher in the case of the positive group ( 0.53 higher with a significance level of 0.018$)$, which also reflects the open attitude of the positive group.

In the survey, 17 motivational factors were measured. To analyse the internal structure of these factors, a factor analysis was conducted. Table no. 7 shows that according to the KaiserMeyer-Olkin (KMO) measure and Bartlett's test, the data are adequate for factor analysis.

Table no. 7: KMO and Bartlett's test

\begin{tabular}{|l|l|r|}
\hline Kaiser-Meyer-Olkin Measure of Sampling Adequacy & .843 \\
\hline Bartlett's Test of Sphericity & Approx. Chi-Square & 782.425 \\
\hline & df & 136 \\
\hline & Sig. & .000 \\
\hline
\end{tabular}

Tables no. 8 and 9 show the results of the factor analysis of the motivational factors. The number of factors is displayed, and the total variance is explained. The number of factors was determined by the components with an eigenvalue over 1 . This criterion resulted in 4 factors overall. To improve the results, a varimax rotation and a cut-off value of 0.42 for item loadings were used. The items that loaded on multiple factors with loadings of at least 0.42 were omitted, and the factor analysis was rerun on the remaining items. (There were three such items, namely, the expectations of the local community, supply chain requirements and defined specifications.) The final results are shown in Tables no. 8 and 9.

Table no. 8 contains only the components with an eigenvalue over 1 . It can be observed that 4 factors explain $63.8 \%$ of the total variance, which is a good result.

Table no. 8: Total variance explained

\begin{tabular}{|l|c|c|c|c|c|c|c|}
\hline \multirow{2}{*}{ Component } & \multicolumn{3}{|c|}{ Initial Eigenvalues } & \multicolumn{3}{c|}{$\begin{array}{c}\text { Extraction Sums of Squared } \\
\text { Loadings }\end{array}$} & $\begin{array}{c}\text { Rotation } \\
\text { Sums of } \\
\text { Squared } \\
\text { Loadings }\end{array}$ \\
\cline { 2 - 9 } & Total & $\begin{array}{c}\text { \% of } \\
\text { Variance }\end{array}$ & $\begin{array}{c}\text { Cumulative } \\
\%\end{array}$ & Total & $\begin{array}{c}\text { \% of } \\
\text { Variance }\end{array}$ & $\begin{array}{c}\text { Cumulative } \\
\%\end{array}$ & Total \\
\hline 1 & 5.904 & 36.899 & 36.899 & 5.904 & 36.899 & 36.899 & 3.072 \\
\hline 2 & 1.845 & 11.534 & 48.433 & 1.845 & 11.534 & 48.433 & 2.952 \\
\hline 3 & 1.362 & 8.515 & 56.948 & 1.362 & 8.515 & 56.948 & 2.379 \\
\hline 4 & 1.097 & 6.855 & 63.803 & 1.097 & 6.855 & 63.803 & 1.806 \\
\hline
\end{tabular}

The first factor collects the items, which define the current purchasing environment; these are the circumstances in which the purchasing job is to be performed. The second factor collects the items of regulatory power; these are the conditions that purchasers should comply with and is called the factor of compliance. The third factor collects the financial items, and it connects the value of the purchase with the cost saving targets. (The cost saving target was 
important to all groups.) The fourth factor connects demand fluctuation with competitors' activity, which are two motivational factors of low importance.

Table no. 9: Factor analysis of the motivational factors (rotated component matrix)

\begin{tabular}{|l|r|r|r|r|}
\hline & \multicolumn{4}{|c|}{ Component } \\
\cline { 2 - 5 } & 1 & 2 & 3 & \multicolumn{1}{c|}{4} \\
\hline Value & .122 & .053 & $\mathbf{. 7 9 0}$ & .288 \\
\hline Demand fluctuation & .163 & .087 & .342 & $\mathbf{. 7 6 8}$ \\
\hline Number of suppliers & $\mathbf{. 7 6 7}$ & .036 & .239 & .063 \\
\hline Market position of purchasing & $\mathbf{. 5 6 7}$ & .092 & .394 & .170 \\
\hline Environmental consciousness of purchasers & $\mathbf{. 5 7 1}$ & .410 & .094 & .148 \\
\hline Environmental regulations, laws & .387 & $\mathbf{. 6 6 4}$ & .169 & -.208 \\
\hline Customer expectations/market demand & .219 & $\mathbf{. 5 1 2}$ & .311 & .385 \\
\hline Cost saving targets & .149 & .279 & $\mathbf{. 7 9 2}$ & -.023 \\
\hline Production/operation attributes & $\mathbf{. 6 7 2}$ & .244 & .314 & .054 \\
\hline Environmental targets & .416 & $\mathbf{. 6 4 0}$ & .068 & -.120 \\
\hline Availability of environmental information & $\mathbf{. 6 6 1}$ & .309 & -.220 & .359 \\
\hline Competitors' activity & .183 & .372 & .053 & $\mathbf{. 7 6 8}$ \\
\hline Motivation of the owners/parent company & -.100 & $\mathbf{. 8 0 3}$ & .042 & .290 \\
\hline Top management support & .154 & $\mathbf{. 7 9 0}$ & .113 & .168 \\
\hline
\end{tabular}

Notes: Extraction Method: Principal Component Analysis.

Rotation Method: Varimax with Kaiser Normalisation.

Rotation converged in 9 iterations.

This factor structure supports the assumptions of the motivational attitude model because it connects to the factors, which can be easily connected to the elements of the model.

\subsection{Personal attitudes and activities}

Two sets of questions addressed the differences in the identified green purchasing activities based on the previously described literature. Because a large number of activities were identified, they were grouped into 'internal' and 'supplier-related' activities.

\subsubsection{Internal activities of green purchasing}

Internal activities were identified as the activities that involve collaboration with other management fields in the firm. The respondents indicated the extent of involvement on a 1 to 5 scale in which 5 means strong involvement and 1 means no involvement.

As Table no. 10 shows, the involvement indicated by the positive-attitude group is higher than or equal to the involvement of the compliance group. The results of the ANOVA analysis show differences at a 0.05 significance level in the case of 'the design of more environmentally friendly products', 'design of products for reuse or recycling', 'design of products to reduce the use of hazardous product content' and 'preparation of design specifications that include environmental requirements'. 
Table no. 10: Internal activities according to the personal motivation attitudes

\begin{tabular}{|l|r|r|r|}
\hline & Avoidance & Compliance & Positive \\
\hline $\begin{array}{l}\text { Design of more environmentally friendly } \\
\text { products }\end{array}$ & 1.47 & 2.00 & 2.74 \\
\hline Design of products for reuse or recycling & 1.33 & 2.03 & 2.65 \\
\hline $\begin{array}{l}\text { Design of products to reduce } \\
\text { the use of hazardous product content }\end{array}$ & 2.00 & 2.59 & 3.19 \\
\hline $\begin{array}{l}\text { Design of products to reduce the use } \\
\text { of hazardous products in their production }\end{array}$ & 2.33 & 2.44 & 2.84 \\
\hline Design of processes to minimise waste & 2.33 & 3.05 & 3.00 \\
\hline Collection and reuse of used material/products & 2.33 & 2.97 & 3.48 \\
\hline Reuse of defective products & 2.13 & 2.49 & 2.71 \\
\hline $\begin{array}{l}\text { Preparation of design specifications } \\
\text { that includes environmental requirements }\end{array}$ & 1.80 & 2.37 & 2.87 \\
\hline Sale of excess inventory and materials & 2.73 & 3.22 & 3.03 \\
\hline Sale of scrap and used material & 2.40 & 3.13 & 3.10 \\
\hline Sale of excess capital equipment & 1.93 & 2.89 & 3.06 \\
\hline Company-wide environmental audits & 1.67 & 2.78 & 2.77 \\
\hline
\end{tabular}

These ANOVA results indicate a difference concerning the product-related activities, while the activities related to the involvement in source reduction and green logistics in the positiveattitude group were not significantly better than or equal to the compliance group. The only exception was 'the design of products to reduce the use of hazardous products in their production'. Although this exception is a product-related activity, involvement is not significantly higher according to the ANOVA analysis. The reasoning may be that although 'the design of products to reduce the use of hazardous products in their production' is a product-related activity, it requires knowledge of processes.

\subsubsection{Supplier-related activities of green purchasing management}

Supplier-related activities were identified and are described in Table no. 11. The answers of the personal-motivation group regarding their supplier-related activities are also included in Table no. 11. (The respondents indicated the extent of involvement on a 1-5 scale in which 5 indicates strong involvement and 1 indicates no involvement.)

The respondents assigned low values to each practice item. The positive group indicated above-average values (above 3 on a 1-5 scale) for 6 practice items. These items are descriptive in nature.

Table no. 11: Supplier-related activities and personal motivation

\begin{tabular}{|l|r|r|r|}
\hline & Avoidance & Compliance & Positive \\
\hline $\begin{array}{l}\text { Supplier evaluation includes environmental } \\
\text { requirements for purchased items }\end{array}$ & 2.07 & 2.59 & 3.55 \\
\hline $\begin{array}{l}\text { Supplier evaluation includes environmental } \\
\text { requirements for the suppliers'operations }\end{array}$ & 1.80 & 2.32 & 3.42 \\
\hline $\begin{array}{l}\text { Supplier evaluation includes environmental } \\
\text { requirements for packaging }\end{array}$ & 1.93 & 2.65 & 3.39 \\
\hline
\end{tabular}




\begin{tabular}{|l|r|r|r|}
\hline & Avoidance & Compliance & Positive \\
\hline $\begin{array}{l}\text { Product lifecycle analysis is part of the suppliers' } \\
\text { evaluation }\end{array}$ & 1.73 & 2.49 & 2.94 \\
\hline Product content restrictions & 2.93 & 2.98 & 3.55 \\
\hline $\begin{array}{l}\text { Disclosure of the environmental attributes of } \\
\text { product content by the supplier is required }\end{array}$ & 1.93 & 2.40 & 3.58 \\
\hline Supplier is required to have ISO 14000 & 1.80 & 2.46 & 3.07 \\
\hline Asking suppliers to commit to waste reduction goals & 1.80 & 2.46 & 2.87 \\
\hline Environmental assessment of suppliers' processes & 1.80 & 2.27 & 2.90 \\
\hline Setting environmental standards for suppliers & 2.33 & 2.16 & 2.61 \\
\hline $\begin{array}{l}\text { Cooperation with suppliers to develop more } \\
\text { environmentally better products }\end{array}$ & 1.87 & 2.05 & 2.61 \\
\hline Educating suppliers on environmental issues & 1.60 & 1.83 & 2.26 \\
\hline
\end{tabular}

The ANOVA analysis revealed that there are differences in many supplier-related activities between the positive and compliance groups. The group of people who indicated positive personal attitudes associated higher activity in almost all cases and indicated higher activity (at a significance level of 0.05 ) in 7 out of 12 cases. Four out of five items are not significantly better items (Product lifecycle analysis is part of the suppliers' evaluation, Product content restrictions, setting environmental standards for suppliers, asking suppliers to commit to waste reduction goals, and Educating suppliers on environmental issues) and require special methods or environmental management expertise. This result may be closely related to the results of the motivational factors; here, the lack of information is a major barrier.

\section{Conclusion and agenda for future research}

The aim of this paper was to investigate the background of the differences in green purchasing practices. The role of the personal motivational attitudes of the respondent purchasing managers is emphasised to address the gap identified in the literature. The relatively small and single country sample is a limitation. In the database there were only two firms, which potentially had bioeconomic practices. A larger study could expand this group and provide more information regarding the role of human attitudes.

The findings indicate that there are differences in green purchasing practices according to the personal attitudes of the purchaser, and differences were identified in their motivation, although legislative power was strong for each group. So the hypothesises of the research (H1, H2A and H2B) can be accepted.

Concerning the compliance group, customer/market demand and management/owner related influences were significant. For the positive group, internal conditions and customer/market demand were strong. The role of information availability was also important for this group.

There were differences in the internal involvement of green purchasing activities and supplier management practices. The positive group indicated higher activity than the sample average in each case. However, most activities that were indicated as significantly higher did not require in-depth processes or management knowledge. These activities reflect the intention to support green initiatives, but their influence on internal processes or the supply chain may be marginal. This finding suggests that a positive attitude in most cases may not be supported by sophisticated methods, and decisions and activities may not be based on sound information. 
The avoidance group had too few responses to provide reliable results. However, these results indicate different motivations and a lower activity in the case of each supplier management practice item. It may be worthwhile to address these differences in future research. The avoidance group tended to be cost focused, and the legislative, owner and management influences on green practices were lower. Another potential research topic is to develop an understanding of bioeconomy means for purchasing: identify relevant activities and practices. As this research highlighted the information about potentially applicable practices is important in case of purchasers with positive attitude. This may also help to motivate those, who have negative attitude at the moment.

\section{Acknowledgment}

The authors gratefully acknowledge the financial support of NKFI (project no K124644).

\section{References}

Appolloni, A., Sun, H., Jia, F. and Li, X., 2014. Green procurement in the private sector: a state of the art review between 1996 and 2013. Journal of Cleaner Production, 85, pp. 122-133.

Arnold, U., Cox, A., Debruyne, M., de Rijcke, J., Heindrick, T., Iyogun, P., Liouville, J. and Vörösmarty, G., 1999. A Multi-Country Study of Strategic Topics in Purchasing and Supply Management. Tempe, AZ: Center for Advanced Purchasing Studies Research.

Bowen, F., Cousins, P., Lamming, R. and Faruk, A., 2006. Horses for courses: explaining the gap between the theory and practice of green supply. In: J. Sarkis, ed. 2006. Greening the Supply Chain. London: Springer, pp. 151-172.

Carter, C.R., Ellram, L.M. and Ready, K.J., 1998. Environmental purchasing: benchmarking our German counterparts. International Journal of Purchasing and Materials Management, 34(3), pp. 28-38.

Carter, C.R., Kale, R. and Grimm, C.M., 2000. Environmental purchasing and firm performance: an empirical investigation. Transportation Research Part E: Logistics and Transportation Review, 36(3), pp. 219-228.

Chatfield, C. and Collins, A.J., 2018. Introduction to multivariate analysis. Routledge. New York

Giunipero, L.C., Hooker, R.E. and Denslow, D., 2012. Purchasing and supply management sustainability: drivers and barriers. Journal of Purchasing and Supply Management, 18(4), pp. 258-269.

González-Benito, J., Lannelongue, G., Ferreira, L.M. and Gonzalez-Zapatero, C., 2016. The effect of green purchasing on purchasing performance: the moderating role played by long-term relationships and strategic integration. Journal of Business and Industrial Marketing, 31(2), pp.312-324.

Green, K.W., Zelbst, P.J., Meacham, J. and Bhadauria, V.S., 2012. Green supply chain management practices: impact on performance. Supply Chain Management: an International Journal, 17(3), pp. 290-305.

Hasan, M., 2013. Sustainable supply chain management practices and operational performance. American Journal of Industrial and Business Management, 3(1), pp. 42-48. 
Hsu, C., Choon Tan, K., Hanim Mohamad Zailani, S. and Jayaraman, V., 2013. Supply chain drivers that foster the development of green initiatives in an emerging economy. International Journal of Operations and Production Management, 33(6), pp. 656-688.

Huang, X., Tan, B.L. and Ding, X., 2015. An exploratory survey of green supply chain management in Chinese manufacturing small and medium-sized enterprises. Journal of Manufacturing Technology Management, 26(1), pp. 80-103.

Jabbour, C.J.C. and de Sousa Jabbour, A.B.L., 2016. Green human resource management and green supply chain management: linking two emerging agendas. Journal of Cleaner Production, 112, pp. 1824-1833.

Kaufmann, H. R., Panni, M. F. A. K. and Orphanidou, Y., 2012. Factors affecting consumers' green purchasing behavior: An integrated conceptual framework. Amfiteatru Economic Journal, 14(31), pp. 50-69.

Khidir, E.T., Zailani, S. and Jayaraman, K., 2010. The examination on the drivers for green purchasing adoption among EMS 14001 certified companies in Malaysia. Journal of Manufacturing Technology Management, 21(2), pp. 206-225.

Kuei, C., Madu, C.N., Chow, W.S. and Chen, Y., 2015. Determinants and associated performance improvement of green supply chain management in China. Journal of Cleaner Production, 95, pp. 163-173.

Lintukangas, K., Kähkönen, A.K. and Ritala, P., 2016. Supply risks as drivers of green supply management adoption. Journal of Cleaner Production, 112, pp. 1901-1909.

Mathiyazhagan, K., Diabat, A., Al-Refaie, A. and Xu, L., 2015. Application of analytical hierarchy process to evaluate pressures to implement green supply chain management. Journal of Cleaner Production, 107, pp. 229-236.

Mathiyazhagan, K., Govindan, K., NoorulHaq, A. and Geng, Y., 2013. An ISM approach for the barrier analysis in implementing green supply chain management. Journal of Cleaner Production, 47, pp. 283-297.

Min, H. and Galle, W.P., 1997. Green purchasing strategies: trends and implications. International Journal of Purchasing and Materials Management, 33(2), pp. 10-17.

Min, H and Kim, I, 2012. Green supply chain research: past, present and future, Logistics Research, 4(1-2), pp. 39-47.

Oláh, J., Sadaf, R., Máté, D. and Popp, J., 2018. The influence of the management success factors of logistics service providers on firms' competitiveness. Polish Jounal of Management Studies, 17(1), pp. 175-193.

Popp, J., Oláh, J., Fekete Farkas, M., Lakner, Z. and Máté, D. 2018. The Relationship Between Prices of Various Metals, Oil and Scarcity. Energies, 11(9), 2392, pp. 1-19.

Rao, P. and Holt, D., 2005. Do green supply chains lead to competitiveness and economic performance?. International Journal of Operations and Production Management, 25(9), pp. 898-916.

Tachizawa, E.M., Gimenez, C. and Sierra, V., 2015. Green supply chain management approaches: drivers and performance implications. International Journal of Operations and Production Management, 35(11), pp. 1546-1566.

Tate, W.L., Ellram, L.M. and Dooley, K.J., 2012. Environmental purchasing and supplier management, EPSM): theory and practice. Journal of Purchasing and Supply Management, 18(3), pp. 173-188. 
Theyel, G. and Hofmann, K. H., 2015. Environmental practices and innovation performance of US small and medium-sized manufacturers. Journal of Manufacturing Technology Management, 26(3), pp. 333-348.

Torjai, L., Nagy, J., and Bai, A., 2015. Decision hierarchy, competitive priorities and indicators in large-scale 'herbaceous biomass to energy'supply chains. Biomass and Bioenergy, 80, pp. 321-329.

Vachon, S. and Klassen, R.D., 2006. Extending green practices across the supply chain. International Journal of Operations and Production Management, 26(7), pp. 795-821.

Vijayvargy, L., Thakkar, J. and Agarwal, G., 2017. Green supply chain management practices and performance. Journal of Manufacturing Technology Management, 28(3), pp. 299-323.

Vörösmarty, G., Dobos, I. and Tátrai, T., 2011. Motivations behind sustainable purchasing. In: R. Burritt, S. Schaltegger, M. Bennett, T. Pohjola and M. Csutora, eds. 2011. Environmental Management Accounting and Supply Chain Management. Dordrecht: Springer, pp. 41-54.

Walker, H., Di Sisto, L. and McBain, D., 2008. Drivers and barriers to environmental supply chain management practices: lessons from the public and private sectors. Journal of Purchasing and Supply Management, 14(1), pp. 69-85.

Younis, H., Sundarakani, B. and Vel, P., 2016. The impact of implementing green supply chain management practices on corporate performance. Competitiveness Review, 26(3), pp. 216-245.

Zhu, Q. and Sarkis, J., 2004. Relationships between operational practices and performance among early adopters of green supply chain management practices in Chinese manufacturing enterprises. Journal of Operations Management, 22(3), pp. 265-289.

Zhu, Q., Sarkis, J. and Geng, Y., 2005. Green supply chain management in China: pressures, practices and performance. International Journal of Operations and Production Management, 25(5), pp. 449-468.

Zhu, Q., Sarkis, J. and Lai, K., 2007. Green supply chain management: pressures, practices and performance within the Chinese automobile industry. Journal of Cleaner Production. 15(11-12), pp. 1041-1052.

Zhu, Q., Sarkis, J. and Lai, K., 2008. Confirmation of a measurement model for green supply chain management practices implementation. International Journal of Production Economics, 111(2), pp. 261-273.

Zhu, Q., Sarkis, J. and Lai, K., 2013. Institutional-based antecedents and performance outcomes of internal and external green supply chain management practices. Journal of Purchasing and Supply Management, 19(2), pp. 106-117.

Zsidisin, G.A. and Siferd, S.P., 2001. Environmental purchasing: a framework for theory development. European Journal of Purchasing and Supply Management, 7(1), pp. 61-73. 


\section{Appendix 1}

1. Value

2. Defined specification

3. Demand fluctuation

4. Number of suppliers

5. Market position of purchasing

6. Environmental consciousness of the purchasers

7. Environmental regulation, laws

8. Customer/market demand
9. Supply chain requirements

10. Cost saving targets

11. Production/operation attributes

12. Environmental targets

13. Availability of environmental information

14. Competitors activity

15. Motivation of the owners

16. Top management support

17. Expectation of local communities 